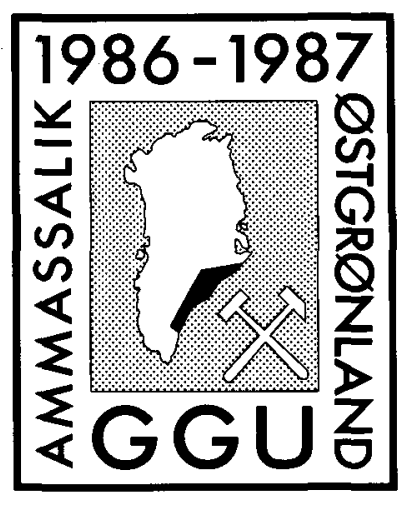

\title{
The Grusgraven locality: border relationships between Precambrian supracrustal rocks and orthogneisses, Kangikajik, South-East Greenland
}

\author{
Peter R. Dawes
}

\begin{abstract}
Kangikajik peninsula in the northern part of the Ammassalik region is composed of a high grade complex of Precambrian gneisses and supracrustal rocks. Amphibolites occur both in the gneisses and supracrustal rocks which are folded together and generally interleaved.

At Grusgraven, a corrie on the south coast, a particularly well-exposed outcrop reveals border relationships between gneiss and supracrustal rocks. These relationships, as well as the internal characters of the rocks, favour a model where the regional gneisses present a basement to a cover sequence composed of metasediments and amphibolites. Whether this involves an Archaean - early Proterozoic association, as isotopically dated elsewhere in the region, is unknown.
\end{abstract}

\section{Introduction}

One of the most fundamental and persistent problems in the study of the crystalline complexes of Greenland has centred on the age relationships of supracrustal belts to gneissic rocks. In this, the Precambrian complex of the Ammassalik region has been no exception. Interpretation of border relationships is of critical importance for the understanding of the chronology and regional geology (Windley et al., 1966).

In repeatedly deformed and polymetamorphic terrains, supracrustal belts and gneisses are generally concordant. The question of whether gneiss or supracrustal rock represents the earliest crustal material can be solved in the field only by the exceptional preservation of primary structures.

In this paper a particularly well exposed, but rather inaccessible, locality in the northern part of the Ammassalik region is highlighted (fig. 1). This may be the most promising exposure in the region for interpretation of the field age relationships between supracrustal and gneissic rocks.

\section{Border relationships in the Ammassalik region}

Wager (1934) recognized in the coastal area of the Ammassalik region widespread belts of 'altered sediments' associated with amphibolites and ultrabasic rocks. These, he noted, were intimately associated with, and injected by, the regional grey orthogneisses sug- gesting that the supracrustal rocks were the older. Wallis (1967), working more inland, adhered to this view. Following regional mapping, Bridgwater \& Gormsen $(1968,1969)$ and Wright et al. (1973) adhered to the opposing view that the gneisses represent a basement to the metasediments and associated rocks. Later, Wager's view came back in vogue although little new critical evidence was forthcoming. It was stated that the gneisses "are intrusive into the supracrustal rocks" (Bridgwater et al., 1978a, p. 6) and the authors did not "regard any of the quartzo-feldspathic gneisses as proven basement to the supracrustals" (Bridgwater et al., 1977, p. 77).

It is pertinent to note that Wager (1934) stressed that the field relationships on which his chronology was based were open to question. He pointed out that the regional gneisses may comprise more than one age of material and that reworking of gneisses has taken place. That supracrustal rocks are transgressed by gneiss is not sound evidence as to the fundamental relative ages of the two rock groups but only an indication of the relative age of the "latest period of flow of the grey gneiss" (Wager, 1934, p. 10).

During field work in 1986, such age discussions as outlined above were rife among the participating geologists and as noted by Kalsbeek \& Nielsen (1987) no unanimous agreement was gained as to the most likely age scenario. On Kangikajik peninsula supracrustal rocks form a main component of the geology (fig. 2). They represent the eastern end of a supracrustal belt 


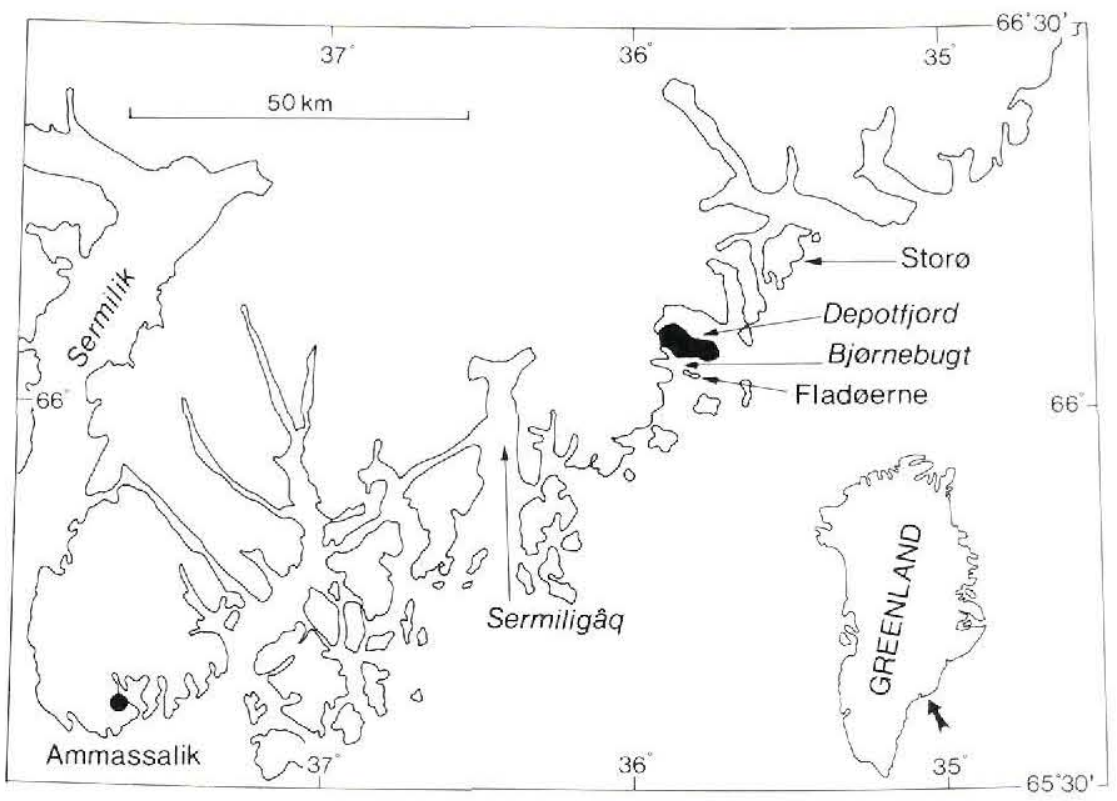

Fig. 1. Location map of Kangikajik peninsula (black) in the Ammassalik region.

that can be traced westwards to at least the head of Sermiligâq (see Dawes et al., this volume - Northern boundary, fig. 3). This paper, as well as discussing gneiss-supracrustal relationships, also provides a first description of the geology of Kangikajik.

\section{Location, accessibility, field work}

Grusgraven is a corrie on the south side of Kangikajik peninsula, about $100 \mathrm{~km}$ north-east of Ammassalik. The corrie faces Bjørnebugt and is located at approximately $66^{\circ} 05^{\prime} \mathrm{N}, 35^{\circ} 50^{\prime} \mathrm{W}$ (figs $1 \& 2$ ).

The corrie exposes a contact between a supracrustal unit and grey regional gneisses; a vertical basic body over $100 \mathrm{~m}$ wide is conspicuous in the gneisses and this penetrates into the supracrustal unit (figs $3 \& 4$ ). The main contact is exposed high in the near vertical backwall of the corrie, the summit of which reaches about $500 \mathrm{~m}$ above sea level. The locality is well seen from Bjørnebugt from where the corrie is accessible although the main contact in the backwall is inaccessible to other than experienced rock climbers. Less steep but poorer exposed sections of the main contact occur both east and west of the backwall. The basic body in the gneiss (inferred to be amphibolite) is accessible above the scree at the base of the backwall.

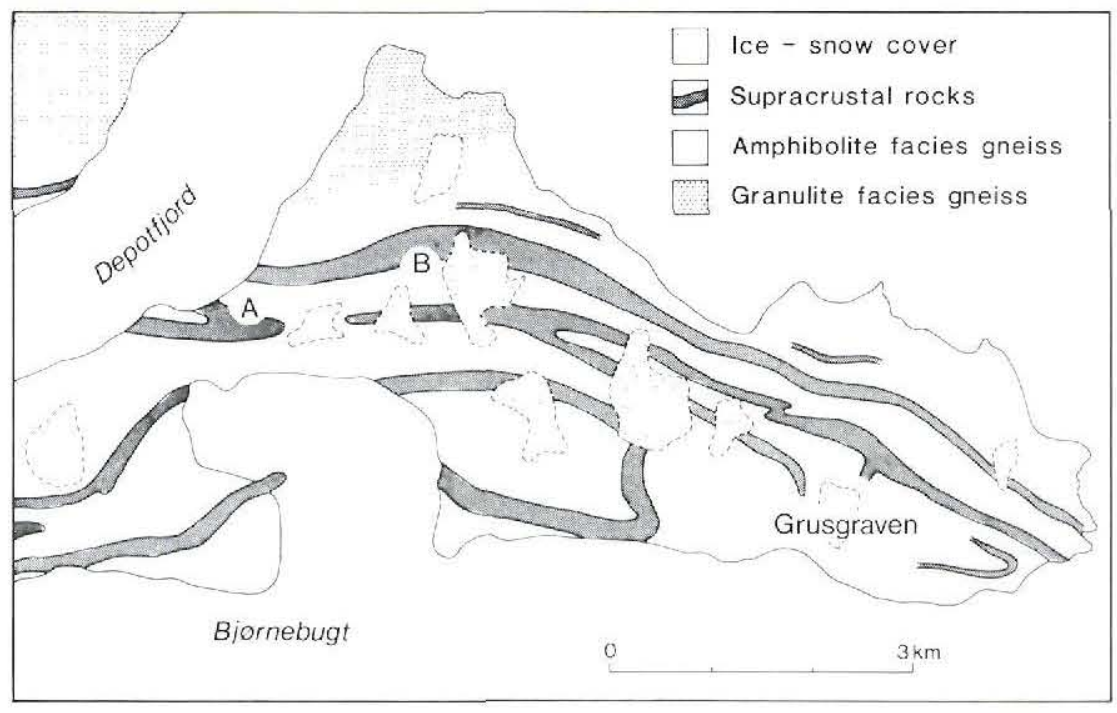

Fig. 2. Geological sketch map of Kangikajik showing location of Grusgraven and main outcrops of supracrustal rocks. Terrain left blank is composed of various gneisses (amphibolite facies), predominantly grey orthogneisses (group 1 in text) and paragneisses (group 3). Prominent NE-trending. Tertiary dyke swarm is not shown. Localities sampled in 1986 are marked A and B. Geology modified from Bridgwater et al. (1976b). 


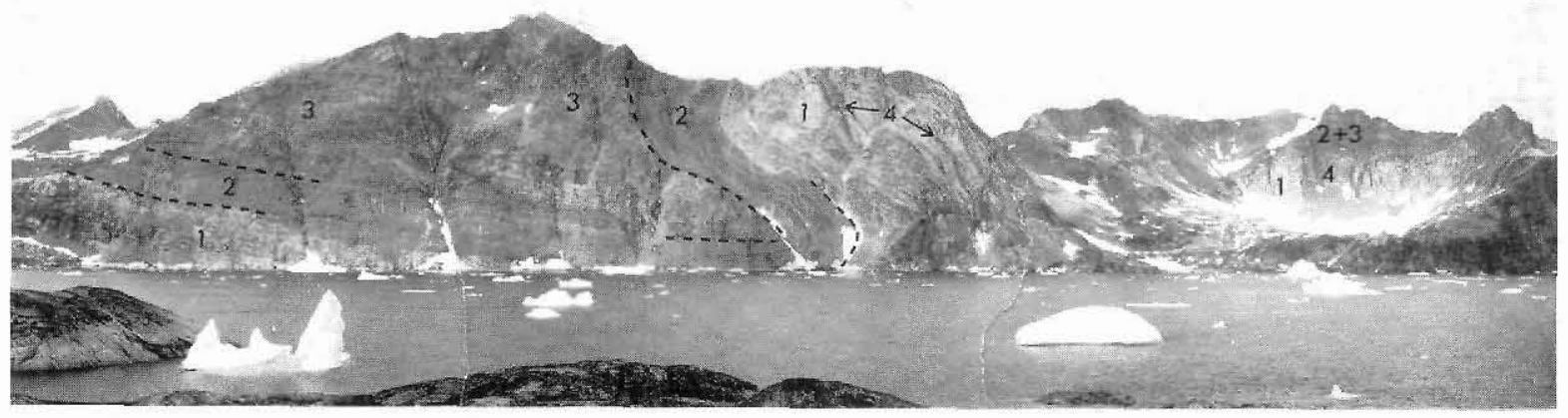

Fig. 3. The south coast of Kangikajik viewed across Bjørnebugt from Fladøerne. Main features are Bjørnebugt synform and to the right the corrie of Grusgraven. The four rock groups are: (1) pale grey regional orthogneisses, (2) supracrustal rocks composed of amphibolite and metasediments, (3) paragneisses and (4) amphibolite within gneiss. The amphibolite layers folded around the hinge of the Bjørnebugt synform were initially described by Wager (1947). Photograph August 1986.

The principal rock types exposed at Grusgraven are represented throughout the Kangikajik peninsula. In 1986, during regional reconnaissance (see Dawes et al., this volume - Northern boundary), Kangikajik was visited by the author and other geologists (N. J. Soper and C. K. Brooks, V. N. Vasudev and G. Stenstrop), and the main rock types were sampled at two localities (A and B, fig. 2). The area immediately south of Kangikajik, including Fladøerne and other islands (fig. 1), were reconnoitred by the author and A. P. Nutman.

Rock relationships at Grusgraven were studied from the air when close-up views of the corrie backwall were obtained from the helicopter (fig. 4). Although no rocks were sampled at Grusgraven rock types are known from the localities examined elsewhere in Kangikajik and in Bjørnebugt.

\section{Geology of Kangikajik}

The spatial relationship of supracrustal rocks to gnejss at Kangikajik is shown in fig. 2 as a simplified sketch map.

The cliffed southern coast of Kangikajik exposes a rusty-weathering supracrustal unit folded by a major synform. In this paper this fold is referred to as the Bjørnebugt synform (fig. 3). Wager (1934, pl. 2) first demonstrated the presence of supracrustal rocks on the peninsula and later illustrated the folded unit describing it as garnetiferous mica schist (Wager, 1947, fig. 1).

The regional disposition of supracrustal rocks on Kangikajik was determined in 1976 by a GGU team (Bridgwater et al., 1977, fig 19). Several coastal localities were visited and samples collected. However, noth-
Fig. 4. Detail of the backwall of Grusgraven showing border relationships between the main discordant amphibolite, pale gneiss and supracrustal unit. Dark units in the latter are mainly amphibolite; the somewhat lighter rocks are metasedimentary schists and paragneiss. Section is cut on the right side by an undeformed NEtrending Tertiary basic dyke. Height of section is about $250 \mathrm{~m}$.

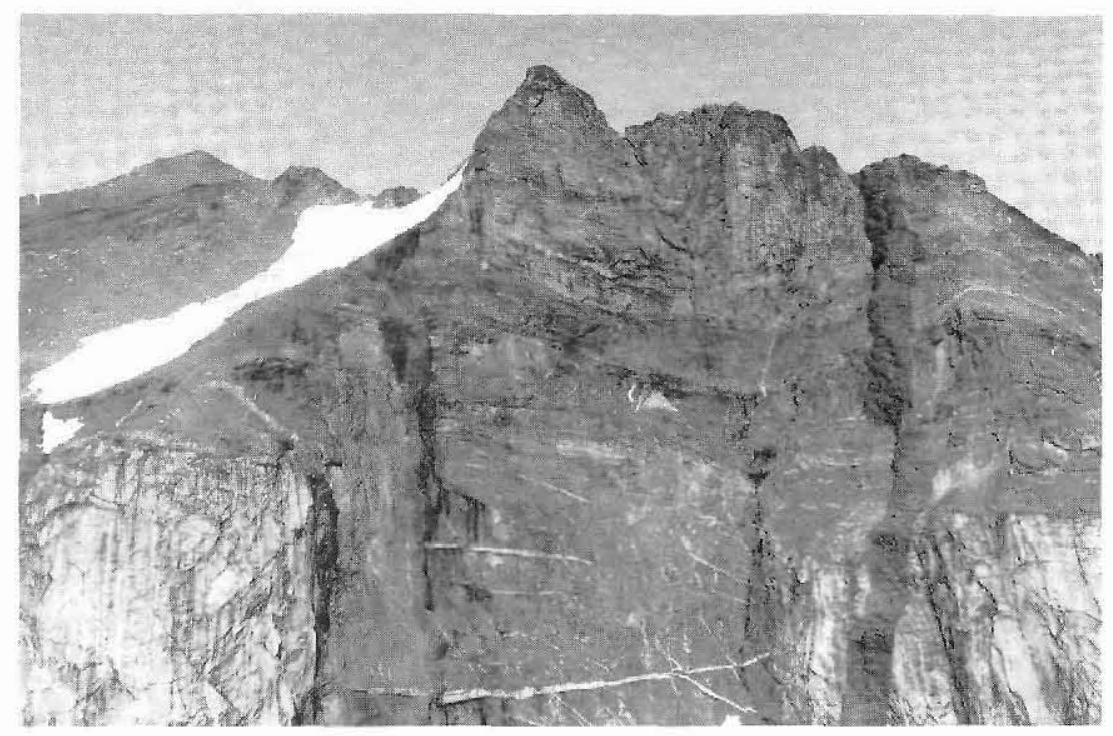


ing specific about Kangikajik was published and no information on the rock outcrops at Grusgraven is given in the unpublished material available to this author (Henriksen, 1976; Gorman, 1976; Bridgwater et al., 1976b).

The main supracrustal outcrops occur as continuous, tightly folded layers up to $300 \mathrm{~m}$ thick within gneisses. The regional foliation of the gneiss and the concordant supracrustal layers are generally steep. On the northern part of the peninsula the geology is dominated by major tight folds trending generally WNW (about $290^{\circ}$ ) with steep axial planes. The Bjørnebugt synform trends NW (about $320^{\circ}$ ) and has an axial plane moderately dipping (about $40^{\circ}$ ) to the NE (Henriksen, 1976). It probably represents a younger structure than the tight upright folds seen to the north. It is possible that the outcrops of supracrustal rocks on Kangikajik represent a single stratigraphical unit; the present disposition may be due to at least two generations of major folds.

Four main rock groups make up Kangikajik and all occur at Grusgraven. These rock groups are distinguished on the photographs presented here of the southern coast of the peninsula (figs $3 \& 4$ ).

\section{Regional gneisses (1)}

Pale grey quartzo-feldspathic gneisses make up a large part of Kangikajik. These rocks show the effects of strong deformation. They are foliated and commonly banded, and more often than not have migmatitic segregations and veins parallel to foliation, as well as later generations of sub-parallel to discordant pegmatitic veins. The main mafic minerals are biotite and hornblende that occur in variable ratios. The rocks are interpreted as multiphase orthogneisses. Some varieties are quartz-poor and approach anorthosites. Mafic banding examined on Fladøerne, south of Grusgraven (fig. 1) is regarded as relict igneous layering and the gneisses there as part of an anorthosite-gabbro complex (A. P. Nutman, personal communication, 1986).

The gneisses are characterised by amphibolite layers in various stages of break-up (see later). At least some of this material represents deformed and metamorphosed basic dykes; some of the amphibolites form persistent layers that on a small scale produce banded gneiss.

The gneisses and associated basic material show amphibolite facies mineral assemblages but textural and mineralogical evidence suggests that the pale gneisses represent retrogressed rocks (see Dawes et al., this volume - Northern boundary). Brown weathering granulite facies gneisses outcrop in northern Kangikajik and in inner Depotfjord, as well as on the southern coast of Bjørnebugt (fig. 1).

\section{Supracrustal amphibolites and metasediments (2)}

Supracrustal units shown on the map (fig. 2) are composed of amphibolite and metasediment in varying proportions. No detailed study of the supracrustal succession has been carried out, but in general amphibolite seems to be the dominant rock type. At localities A and B (fig. 2) amphibolite probably constitutes less than 50 per cent of the sequence; in the Bjørnebugt synform unit amphibolite predominates (Henriksen, 1976).

The amphibolites are dark to rusty weathering and range from fine-grained rather homogeneous rocks with gradations to schists to rather coarse-grained and generally lighter coloured amphibolite that shows some compositional variation. This variation takes the form of striping and banding that suggests transposed igneous (?volcanic) structure. Hornblende, biotite and plagioclase are the main minerals; quartz, garnet, clinopyroxene and actinolite also occur. Some amphibolites are conspicuously garnet-rich.

The metasediments are rusty weathering and vary from biotite and graphite schists to psammitic and quartz-rich schists, with minor marble and calc-silicate rocks. Garnet and sillimanite occur in the pelitic schists; diopside, garnet, phlogopite and graphite in the carbonate rocks. Graphite, both crystalline and amorphous varieties, is concentrated in pelitic lithologies in bands 1-2 m thick and in amounts that warrant further economic assessment. Sulphides also occur in both pelitic and psammitic lithologies.

\section{Paragneisses (3)}

Units of paragneiss occur on Kangikajik, although on the map these are not distinguished from the pale gneisses. The rocks are darker in colour than the regional gneisses having a brownish to rusty-weathering hue. The rocks show considerable variation, and gradations exist to the supracrustal rocks as well as the pale gneisses. The paragneisses are migmatised by streaks, lenses and thin veins of leucocratic material. Garnet and sillimanite are the main metamorphic index minerals noted, in addition to plagioclase, quartz and mica.

\section{Amphibolite within gneiss (4)}

In addition to the amphibolite layers in the supracrustal units, amphibolite rocks occur within the pale gneisses. These amphibolites are of a variety of forms and are certainly of more than one age. Some lenses and pods probably pre-date the formation of the regional foliation; other generally more continuous bodies transgress it. 


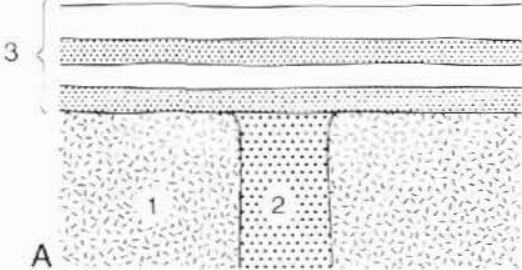

A

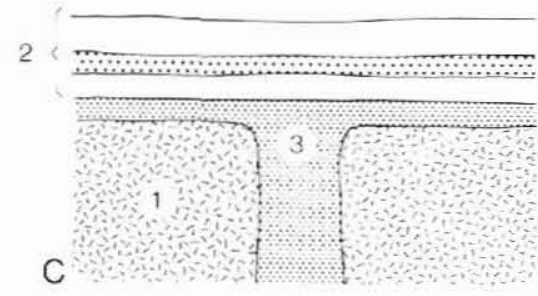

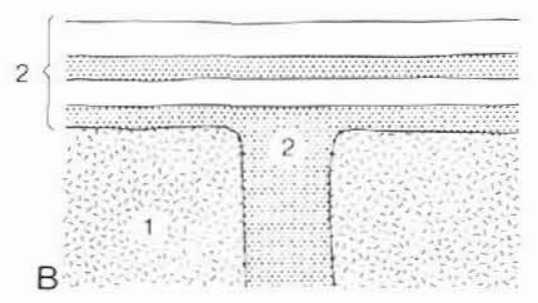

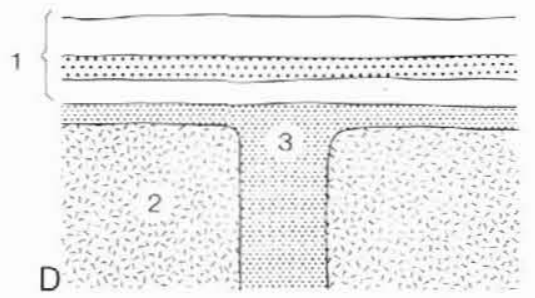

Fig. 5. Schematic diagram illustrating four possible relationships between regional orthogneisses (cross hatched symbol) and supracrustal rocks. Amphibolite is shown by dotted symbols; metasediments are left blank. Numbers 1 to 3 indicate the relative ages of rock units with no. 1 the oldest. The observed relationships on Kangikajik are covered by case $B$.
The amphibolites vary from thin parallel-sided dykes to more irregular, even pinch-and-swell forms, as well as disorganised deformed dyke remnants and isolated lenses and blocks. A common form, illustrated by the amphibolites mentioned by Wager (1934) that follow around the hinge of the Bjørnebugt synform (fig. 3), are fairly continuous concordant layers. Such layers are generally up to $10 \mathrm{~m}$ or so thick, but several linear bodies within pale gneisses on the south coast of Bjørnebugt are over $100 \mathrm{~m}$ across (Bridgwater et al., 1976b).

\section{Rock relationships at Grusgraven}

From the helicopter the following interpretations were made of the rock relationships at Grusgraven.

1. The main contact between the pale gneisses and the supracrustal unit is abrupt; migmatitic veins in the gneisses appear not to penetrate the amphibolites or metasediments.

2. No gross structural discordance could be discerned at the main contact between the supracrustal unit and the pale gneisses.

3. The main amphibolite body is discordant to the gneiss structure (migmatitic veining) and is thus younger in age than the gneiss.

4. The main amphibolite body appears to continue into (and thus is probably contemporaneous with) the amphibolite in at least the lower part of the supracrustal unit.

5. The main amphibolite body and the amphibolite layers in the supracrustal unit have the same gross character: they have a foliation and are cut by thin discordant acid veins that also penetrate the pale gneisses.

6. The amphibolite and metasediments making up the supracrustal unit are intimately associated and interleaved; no gross discordances were discerned.

Several possible interpretations of the Grusgraven locality are schematically shown in fig. 5. The relationships 3 and 4 listed earlier are particularly important. The association of the main amphibolite body in the gneiss with the supracrustal unit excludes the situation shown as case $\mathrm{A}$ in fig. 5 . The main discordant amphibolite body in the pale gneisses is either connected to supracrustal amphibolites, i.e. the latter are metavolcanic and/or coeval 'sills' (case B), or divorced from the supracrustal episode (cases C and D). If the discordant amphibolite does represent an unrelated hypabyssal episode, it might have intruded a supracrustal unit that is either younger (case C), or older (case D) than the pale gneisses.

The relationship listed earlier as 4 is most critical. If the amphibolites in the lower part of the supracrustal unit at Grusgraven are of supracrustal origin, a basement-cover relationship exists.

As mentioned earlier, the folded outcrops of supracrustal rocks on Kangikajik may essentially represent a single stratigraphic sequence. Observations in 1986 suggest that the bulk of the amphibolite making up the supracrustal unit is of the same age as the intercalated metasediment. The amphibolites and metasediments cannot be separated chronologically; both rock types appear to have passed through the same tectonometamorphic history. This conclusion is supported by observations from the Bjørnebugt synform made by Henriksen (1976) who describes the supracrustal unit as predominantly composed of garnet-bearing supracrustal amphibolite with relatively thin layers up to $5 \mathrm{~m}$ thick of biotite-garnet schist with minor marble. Henriksen 
drew a clear distinction between such supracrustal amphibolite and the generally less deformed and younger amphibolites that occur both in the adjoining gneisses and in the supracrustal amphibolites, as dykes and subconcordant layers.

The above observations suggest that the bulk of the amphibolites on Kangikajik are an integral part of a supracrustal sequence. There is no evidence to suggest that the amphibolite components are of a much later age than the metasediments; in general, later amphibolite phases in both gneiss and supracrustal rocks can be recognised by their less deformed nature. Bridgwater $e t$ al. (1977) regarded the supracrustal units of the region (including Kangikajik) to be composed of metasedimentary rocks and contemporaneous "amphibolitic rocks of basaltic composition".

Added to the above evidence is the contrast in tectonometamorphic history recognised in the complexly folded and migmatised pale gneisses and the supracrustal rocks. The 1986 observations are again supported by those of Henriksen (1976) who noted that the supracrustal amphibolites in the Bjørnebugt synform are conspicuously less deformed than the underlying pale gneisses. In particular, he reported the presence of intense migmatitic veining and early interfolial folds in the gneiss, features not present in the adjacent supracrustal amphibolite.

On the basis of the above observations and interpretations, it is suggested that the main amphibolite layers in the supracrustal units on Kangikajik are contempora- neous with the metasediments and represent metavolcanics or coeval intrusions. The apparent connection between these amphibolites and the main discordant amphibolite in the main gneisses at Grusgraven indicates that the supracrustal rocks are younger than the pale gneisses inferring the presence of a basement-cover relationship (case B, fig. 5).

\section{Age of the rocks}

No isotopic dating of the rocks at Kangikajik has been carried out, but about $15 \mathrm{~km}$ to the north-east (island of Stor $\varnothing$, fig. 1) shear-zone rock in retrogressed granulite facies gneiss has been dated by the $\mathrm{Rb}-\mathrm{Sr}$ whole rock method as Archaean (Pedersen \& Bridgwater, 1979). Recent isotopic work has confirmed that the regional gneisses in the northern part of the Ammassalik region represent Archaean crust (Kalsbeek \& Taylor, this volume).

Isotopic age work on rocks collected in 1986 strongly suggests that supracrustal rocks in the Sermilik area, about $100 \mathrm{~km}$ to the west of Kangikajik (fig. 1), are of early Proterozoic age (Kalsbeek \& Taylor, this volume). Thus an Archaean basement - Proterozoic cover relationship is now inferred for at least some of the supracrustal-gneiss associations in the Ammassalik region. It would seem logical to infer this age relationship for the rocks at Grusgraven. However, until further work has been carried out the presence of appreciable Archaean supracrustal rocks in the region cannot be discounted. 